\title{
ОСНОВНАЯ СЕМЬЯ: ПРЕДЫСТОРИЯ И ПЕРСПЕКТИВЫ
}

\author{
ИРИНА ЕЛИСЕЕВА
}

\begin{abstract}
Рассматривается траектория изменений в составе и величине российской семьи в советский период: переход от преобладания сложной семьи к преобладанию простой семьи, от многодетности $\kappa$ малодетности. Акиентируется воздействие государства на российскую семью через законодательство. Выделяется переход от политики расшатывания семейного уклада в 1918-1920 г2. к формированию имиджа семьи как «основной ячейки общества», вступления в брак как государственного деяния. Подчеркивается воздействие законодательства на репродуктивное поведение, прежде всего незамужних женщин, оказавиихся в ловушке традиционной морали. Отмечается сущуественное влияние половых диспропоричй на брачность после Великой отечественной войны. Развитие российской семьи связывается с жилищными условиями и формированием рынка жилья. Среди нуклеарных семей вылеляется семья «родители-дети», которая интерпретируется как основная семья с позиций демографического и социального воспроизводства, непосредственности контактов двух поколений. Подчеркивается равноправность признаков основной семьи: наличие гетерогенной брачной пары и несовершеннолетних детей. По данным Комплексного обследования уровня жизни населения 2018 2. показано, что брачные пары без детей имеют большую долю в выборочной семейной структуре, нежели брачные пары с детьми. Так что семьи, трактуемые как основные с позиций репродуктивного потенциала, оказываются неосновными по своей представительности.
\end{abstract}

Возрастает разнообразие семей, основные семьи трансформируются, приобретая новые характеристики, не свойственные традиционным признакам семьи; трансформация затрагивает также характер супружеских и внутрисемейных отношений. Отмечаются узкие места отечественной статистики, затрудняющце анализ брачно-семейных отношений. Делается вывод об амбивалентности современного российского общества, нелинейности процесса модернизации семьи, включающего возвратные тенденции.

Ключевые слова: основная семья, семейная структура, брачная пара, законодательство, несовершеннолетние дети, тип семьи, женский перевес, аборт, жилище, тенденщия.

\section{ВВЕДЕНИЕ}

Россия - семейная страна. Свыше $80 \%$ населения живет в семьях/частных домохозяйствах. Брак, семья, дети сохраняют свою значимость в жизненных ценностях россиян. Современная российская семья, модернизируясь, представляет множество разнообразных типов: простые семьи и сложные, включающие родственников по восходящей ветви (прародители) или же по боковой ветви (братья, сестры, племянники и так далее), полные и неполные, с несовершеннолетними детьми и без детей, с родительским ядром и без него и др.

Скорость социальных и экономических изменений приводит к появлению новых форм семейной жизни, в большей степени отвечающих потребностям людей. Растет доля неполных семей, сохраняют свою представительность сложные семьи, социально значимой становится категория free-child family и так далее.

\footnotetext{
ИРИНА ИЛЬИНИчНА ЕЛИСЕЕВА (irinaeliseeva@mail.ru), САНКТ-ПЕТЕРБУРГСКИЙ ГОСУДАРСТВЕННЫЙ ЭКОНОМИЧЕСКИЙ УНИВЕРСИТЕТ, СОЦИОЛОГИЧЕСКИЙ ИНСТИТУТ РАН - ФИЛИАЛ ФЕДЕРАЛЬНОГО ГОСУДАРСТВЕННОГО БЮДЖЕТНОГО УЧРЕЖДЕНИЯ НАУКИ ФЕДЕРАЛЬНОГО НАУЧНО-ИССЛЕДОВАТЕЛЬСКОГО СОЦИОЛОГИЧЕСКОГО ЦЕНТРА РОССИЙСКОЙ АКАДЕМИИ НАУК, РОССИЯ.
} 
Но во всем многообразии современной семьи основным типом семьи остается брачная пара с несовершеннолетними детьми (независимо от способа появления детей, естественного или искусственного, включая суррогатную мать). Семьи этого типа принимают на себя ответственность за будущее; члены брачной пары находятся в трудоспособном возрасте, они обладают большим ресурсом как репродуктивным, так и экономическим и социальным (Жеребин 2010: 29-35). Семьи «родители-дети» более динамичны и восприимчивы к социально-культурным изменениям, склонны к коллективному освоению бытовых технических новинок, к самообучению и взаимодействию. Наконец, семьи этого типа составляют значительную часть российских семей. Несмотря на, казалось бы, безоговорочно приоритетную роль таких семей, они редко рассматриваются как самостоятельный объект исследования. Нет согласия даже в определении этой категории семьи. В соответствии с одним определением брачная пара с детьми составляет нуклеарную семью (Cambridge Dictionary ${ }^{1}$ ); в других определениях к категории нуклеарных относится и бездетная брачная пара (Чижова, Шестакова, Пунина 2010: 61). При таком понимании главным признаком нуклеарной семьи оказывается наличие одной гетерогенной брачной пары. Для других российских исследователей характерно отождествление нуклеарной семьи с простой семьей, для которой главным является выступает отсутствие прочих родственников (Ружже, Елисеева, Кадибур 1983). В таком случае к нуклеарным относятся не только брачные пары с детьми или без детей, но и неполные семьи. Отмеченные пересечения в определениях нуклеарной семьи дают основания считать гетерогенную брачную пару с несовершеннолетними детьми самостоятельной группой и идентифицировать этот тип как основную семью (The Main Family). Это, прежде всего, объясняется их ведущей ролью в реализации репродуктивной функции семьи. К тому же они транслируют свои знания и опыт детям через непосредственное общение, не перекладывая их воспитание на родственников. Такая семья в полной мере может рассматриваться «как встреча поколений». Система отношений в такой семье создает базу для восприятия детьми брака и семьи; в ней возникают новые формы отношений между детьми и родителями в более остром и открытом виде, чем в семьях с прочими родственниками. В качестве признаков отнесения к таким семьям одинаково важно как наличие полной брачной пары, так и одного или нескольких несовершеннолетних детей. Собственно этот тип семьи «родители-дети» всегда отождествлялся с понятием семьи в традиционном сознании. В отечественных публикациях можно указать ряд работ, в которых содержатся примерно такие же рассуждения относительно семей с брачной парой и несовершеннолетними детьми и по отношению к ним используется либо именно данный термин «основная семья» (Синельников 2015: 90) 2 , либо такие семьи называются «основной семейной ячейкой» (Гурко 2017).

Убежденность в первостепенной значимости семьи «общепризнанного» состава обусловила выбор объекта статьи. Предметом исследования является изменение представительности основных семей в структуре частных домохозяйств в советский и постсоветский период и трансформация основных семей, которая все более заметно

\footnotetext{
${ }^{1}$ URL: htttp//dictionary.cambridge.org nuclear

2 А.Б. Синельников называет основные семьи «нормативными семьями» (Синельников 2015: 90-91). 
проявляется в современных условиях. В заключении сделано обобщение и намечены контуры эволюции семьи.

\section{ПРЕДЫСТОРИЯ}

История российской семья хорошо изучена (Васильева 1975; Вишневский 2006; 2008a,b; Вишневский, Захаров, Иванова 2008; 2019; Миронов 2015; 2017; Клецин 2000; Мазур 2015) и др. Исторически российские семьи имели сложный состав. В крестьянской семье совместно проживали брачная пара старшего поколения, их дети; если сыновья стали взрослыми, то добавлялись снохи и дети этих молодых брачных пар. Дочери, выйдя замуж, обычно уходили жить в семью мужа. Так что три, в редких случаях четыре поколения (если были живы прародители) жили совместно: вместе питались, вместе работали, планировали свою жизнь. Преимущественно это было связано с распределением объема работ между членами семьи: чем больше семья, тем большую работу можно выполнить, тем зажиточнее хозяйство. В мещанских, купеческих и дворянских семьях практически всегда кроме родительского ядра и детей постоянно жили прочие родственники и не родственники, но воспринимаемые всеми членами семьи как родственники.

Доминировали многодетные семьи. Коэффициент суммарной рождаемости в годы, близкие к 1-й Всеобщей переписи населения Российской империи 1897 г., составлял 7 рождений на женщину (Андреев, Дарский, Харькова 1998: 131). В последующие годы, включая 1917 г., Коэффициент суммарной рождаемости не опускался ниже 5 рождений на женщину за фертильный период. Такой тип репродуктивного поведения не был связан с планированием семьи, т. е. число рождений не было результатом учета высокой детской смертности и намерения родителей иметь трех-четырех взрослых детей, которые бы обеспечивали их жизнь в старости, как пишет В.А. Борисов (1976: 74). Примерами, подтверждающими многодетность как норму, могут служить как статистические данные, так и персональные биографии, например А.Т. Твардовского (1910-1971), который был четвертым ребенком в семье, или А.А. Зиновьева (1922-2006), который был шестым ребенком, а всего его мать с 1910 по 1935 г. родила 11 детей (Зиновьев 2019: 33). И тот и другой родились и выросли в крестьянских семьях. А.А.Зиновьев в своей книге «Советская эпоха. Исповедь отщепенца» пишет, что мать, родив его и покормив, пошла доить корову и делать другие обычные дела. В члены этой многодетной семьи входили бабушка и дед (Зиновьев 2019: 38). Такая семья, которую по современной классификации принято называть сложной, имела многослойные внутрисемейные связи и отношения, которые чаще всего регулировались главой семьи - мужчиной старшего поколения и его «доверенными лицами»: женой, старшим сыном и др.

Семьи сложного состава характерны для слаборазвитых обществ. Как отмечал К.Д. Кавелин: «Этот начальный общественный тип играет большую или меньшую роль во всех малоразвитых обществах, но нигде он не получил такого преобладающего значения, нигде не удержался в такой степени на первом плане во всех социальных, частных и публичных отношениях, как у великорусов» (Кавелин 2019: 197). Для такой семьи с жесткой иерархией главными были интересы семьи в целом. Семья воспринималась как крепость, противостоящая миропорядку. Это понимание семьи емко выразил 
М.Е. Салтыков-Щедрин: «Семья это «дом», это центр жизнедеятельности человека, это последнее убежище, в которое он обязательно возвращается отовсюду, куда бы ни призывали его профессия и долг. Далее этого убежища ему некуда идти» (СалтыковЩедрин 1988).

\section{РЕВОЛЮЦИОННЫЙ РАДИКАЛИЗМ}

Первым сигналом изменений в традиционном укладе жизни стал массовый призыв в армию в связи со вступлением России в Первую мировую войну. Из 26 млн мужчин в возрасте 18-43 лет было призвано 14,5 млн, т. е. более 50\% (Нокс 2014: 486). Только новобранцы 1915 г. насчитывали 700 тыс. мужчин в возрасте 21-22 лет (Нокс 2014: 244). Деревня осталась без мужчин, и это не могло не сказаться на образе жизни семьи (хотя можно встретить мнение, что и прежде мужиков не было дома: все на отхожих промыслах (Antsiferov et al. 1930)). Пагубность вступления России в Первую мировую войну начала осознаваться лишь теперь, спустя более чем 100 лет. В оценке прямых военных потерь многие авторы сходятся, называя цифру 2 млн человек, тогда как непрямые потери и потери гражданского населения до сих пор не изучены и не оценены. Но главная потеря - это деформация нравственности, то, что насилие стало восприниматься как норма.

Вступление России в Первую мировую войну можно считать началом крушения архетипа российской семьи. Однако радикальное воздействие государства на семью, на ее формирование, прочность супружеского союза и репродуктивное поведение связано с Октябрьским переворотом 1917 г., что нашло отражение в соответствующих декретах ${ }^{3}$. В сентябре 1918 г. ВЦИК принял Кодекс законов РСФСР об актах гражданского состояния, брачном, семейном и опекунском праве. Цель этих документов состояла в создании условий для формирования «нового человека». Семья как «явление буржуазного общества» должна быть разрушена. Женщина получает права, равные правам мужчин, освобождается от домашних дел и заботы о детях: воспитание детей переходит от семьи к общественным организациям - детским площадкам, детским садам, коммунам и др. Программа решения «женского вопроса» была очерчена В.И. Лениным следующим образом: «Мы втягиваем женщин в работу советского хозяйства, управлений, в законодательство и в правительственную работу. Мы открываем им двери всех курсов и учебных заведений, чтобы повысить их профессиональную и социальную подготовку. Мы основываем общественные кухни и столовые, прачечные и починочные мастерские, ясли, детские сады, детские приюты, воспитательные учреждения всякого рода. Короче, мы всерьез проводим

\footnotetext{
${ }^{3}$ Одним из первых декретов революционного правительства стал декрет от 18 декабря 1917 г. «О гражданском браке, детях и ведении книг актов гражданского состояния», а затем декрет от 19 декабря «О расторжении брака» (Декреты Советской власти 1957: 374-380). Первый из них устанавливал гражданский брак как единственное подтверждение супружеского союза и отменял обязательность церковной регистрации браков и рождений. Второй декрет был нацелен на либерализацию процедуры развода: развод оформлялся по заявлению либо обоих членов брачной пары, либо одного из супругов; причем явка на процедуру оформления развода обоих супругов была необязательна. Права детей, родившихся вне брака, признавались равными правам родившихся в зарегистрированном браке. Уже в 1917 г. был установлен декретный отпуск - по 8 недель до и после родов. Эти декреты были закреплены законодательно в 1918-1920 гг.
} 
требования нашей программы переложить хозяйственные и воспитательные функции индивидуального домашнего хозяйства на общество. Этим путем женщина освобождается от старого домашнего рабства и всякой зависимости от мужа. Ей предоставляется полная возможность деятельности в обществе в соответствии с eе способностями и наклонностями» (Цеткин 1955: 22). Из такого рода действий неизбежно следовал вывод, который сделал Г. Уэллс, посетивший Россию в сентябре-октябре 1920 г.: «Здесь мы, конечно, имеем дело с процессом «разрушения семьи», который идет полным ходом». И далее: «... в городах России наряду с подъемом народного просвещения и интеллектуальным развитием молодежи возросла и ее распущенность в вопросах пола...» (Уэллс 1958: 58-59).

Легкость вступления в брак и такая же легкость развода в условиях низкой культуры сексуальных отношений привели к проблеме репродукции. Регулятором рождаемости стал аборт, но обязательного медицинского сопровождения этой операции не было: аборт мог производиться в любых условиях, что вызывало множество негативных последствий. Постановлением комиссариата здравоохранения и народного комиссариата юстиции «Об искусственном прерывании беременности», принятом 16 ноября 1920 г., аборты в Советской России были легализованы и должны были производиться только в медицинском учреждении. Аборт стал узаконенной составляющей российской жизни.

Столь радикальные изменения в брачно-семейной сфере происходили на фоне масштабной миграции из города в деревню, либо, наоборот, из деревни в город в поисках спасения от голода. Экономика России была разрушена не только затянувшейся мировой войной, но и разгоравшейся Гражданской войной, унесшей не менее 10 млн жизней россиян и вызвавшей волну массовой эмиграции.

В конце 1920-х годов эксперименты свободы брачно-семейных отношений стали вытесняться официальным утверждением семьи как первичной ячейки общества, как некоего скрепляющего монолита. Тем не менее в законодательстве 1926 г. о семье, браке и опеке еще присутствовали «отголоски» революционных свобод: регистрация брака не была обязательной; фактические (незарегистрированные) браки имели равную с зарегистрированными браками силу в отношении наследства и прав детей ${ }^{4}$. В этом же году были предприняты шаги по контролю за абортами: запрещалось произведение абортов первобеременным, а также тем, кто прибегал к этой операции менее полугода назад. 5 декабря 1936 г. была принята сталинская Конституция, а перед этим (27 июня того же года) вышло Постановление ВЦИК и СНК «О запрещении абортов, увеличении материальной помощи роженицам, установлении государственной помощи многосемейным, расширении сети родильных домов, детских яслей и детских садов, усилении уголовного наказания за неплатеж алиментов и о некоторых изменениях в законодательстве о разводах». Процедура развода была усложнена: для официальной

\footnotetext{
${ }^{4}$ Как отмечает О.И. Рудык, кодекс законов о браке, семье и опеке 1926 г. был основным нормативноправовым актом, регулирующим институт брака в 1926-1960 гг.; сохранял юридическую силу вплоть до 1969 г. В РСФСР Кодекс о браке и семье был утвержден 30 июля 1969 г. и введен в действие с 1 ноября 1969 г.. С 1 марта 1996 г. введен Семейный кодекс РФ (Рудык 2015: 21-22).
} 
регистрации развода оба супруга должны были лично явиться в ЗАГС, а также уплатить пошлину.

Запрет абортов не привел к росту рождаемости. Несмотря на риск попасть под уголовную ответственность как для абортируемой женщины, так и для тех лиц, кто участвовал в процедуре аборта, практически сразу подпольные аборты стали важной сферой теневой экономики и сохранили свою роль регулятора рождаемости. Тем самым был внесен еще один вклад в утверждение норм нравственности советского периода.

Государство все сильнее проявляло свою ведущую роль, то залезая в кошельки граждан (займы), то посягая на их время для всякого рода заседаний, собраний, субботников, воскресников. Провозглашенный в революционный период принцип гендерного равенства всячески популяризировался, но одновременно сохранялся глубоко патриархальный стереотип разделения сфер на «мужские» и «женские» в условиях почти полного отсутствия социальной инфраструктуры. Это привело к двойной нагрузке на женщин: работа и дом. Образ женщины - матери и труженицы стал важной составляющей советской идеологии, сливаясь с образом советской семьи. Так что, как отмечают Бим-Бад и Гавров: «Институт семьи, пошатнувшись в 1920-е годы... уже в 1930-е годы не только полностью восстанавливает, но даже укрепляет свои позиции» (Бим-Бад, Гавров 2010: 128129).

Данные городской переписи 1923 г. и Всесоюзной переписи населения 1926 г. показывают, что именно к этому времени простая семья в городах стала основным типом семьи (таблица 1). Но семьи сложного состава еще были достаточно распространены, превышали треть общего числа семей. Приметой времени стала распространенность семей с одним родителем (примерно $11 \%$ от общего числа семей и $24 \%$ среди простых семей). По данным городской переписи 1923 г. выяснилось, что неполные семьи - это в первую очередь результат овдовения, вклад разводов ничтожный: среди женщин в возрасте 15 лет и старше вдов было 20,4\%, а разведенных всего лишь 1,03\% (Васильева 1985: 20). Средний размер городской семьи по данным обеих переписей составлял 4 человека. А.Г. Волков приводит более точные данные о среднем размере городской семьи: по данным городской переписи 1923 г. - 4,04 человека, по данным всесоюзной переписи 1926 г. - 3,92 человека (Волков, Сороко 1999). По данным первой всесоюзной переписи населения 1926 г. стало очевидно доминирование семьи с одной брачной парой с детьми или без детей.

Таблица 1. Распределение городских семей РСФСР по демографическим типам, \%*

\begin{tabular}{lr}
\hline Тип семьи & 1926 \\
\hline Брачная пара с детьми и без детей & 58,0 \\
Мать (отец) с детьми & 9,4 \\
Итого простые семьи & 67,4 \\
Брачная пара детьми и без детей с родителями одного из супругов и другими родственниками & 17,3 \\
Мать (отец) с детьми, родителями и другими родственниками & 14,0 \\
Итого сложные семьи & 31,3 \\
Прочие семьи & 1,3 \\
Всего & 100 \\
\hline
\end{tabular}

Источник: (ЦСУ СССР 1933: 74).

Примечание: *-Разработка материалов переписи 1923 г. по родственным связям не проводилась. 
Таблица 1 основана на принятой в официальной статистике группировке семей по наличию брачной пары. При этом первыми всегда указываются семьи с полной брачной парой как имеющие в своем составе одного или нескольких несовершеннолетних детей, так и без детей. Это смешение «детных» и «бездетных» не позволяет установить долю «основных семей», т. е. семей с обоими родителями и детьми. Тем не менее очевидно, что переход от крестьянской семьи к городской уже состоялся и относится он к периоду 1923-1926 гг. Этот вывод сделан А.Г. Вишневским (2008b: 10-13). В селах распад многопоколенной семьи был завершен коллективизацией. Традиционные многопоколенные семьи перестали быть основным типом семьи в России (Волков 1999).

\section{СОЦИАЛЬНАЯ ДИФФЕРЕНЦИАЦИЯ, ГЕНДЕР И ДЕФИЦИТ}

Из социальных проблем конца 1920-х и 1930-х годов самой острой для россиян, хлынувших в города, стала проблема жилья. И это был не «квартирный вопрос» по М. Булгакову, а вопрос спального места, которое нередко могло быть только на полу маленькой тесной комнаты или «на ящике для картошки» (Зиновьев 2019: 58). По данным городской переписи 1923 г. свыше 20\% рабочих и членов их семей имели жилищную обеспеченность 3 м²/чел. К 1926 г. положение ухудшилось: число жителей в занятых квартирах возросло на 22,5\%, под жилье отдавались нежилые дома и нежилые помещения в жилых домах. По данным переписи 1926 г. в среднем на одну комнату приходилось 2,7 жителя (ЦСУ СССР 1928b: 910). Как отмечает С. Бойм, «вместо строительства новых жилых массивов и садов-городов, советское правительство в конце 20 -х годов отдало распоряжение начать реконструировать под коммунальные квартиры старый жилищный фонд. С тех пор на долгие годы коммунальные квартиры стали неотъемлемой компонентой повседневности горожан» (Бойм 2002: 167), а также «лабораторией советской жизни... где осуществлялся контроль над социалистическим общежитием. Этому способствовало введение прописки и системы внутренних паспортов» (Бойм 2002: 169).

В конце 1920-х - начале 1930-х годов все отчетливее и масштабнее стала проявляться социальная дифференциация. Андре Жид в своей книге «Возвращение из СССР» писал: «Посмотрите, что происходит в СССР: их новая складывающаяся буржуазия имеет те же самые недостатки, что и наша. Едва выбившись из нищеты, они уже презирают нищих. Жадная до всех благ, которых она была лишена так долго, она знает, как надо их добиваться и держится за них из последних сил» (Жид 1990: 135).

Семейное воспитание публично подвергалось критике в пользу детских дошкольных учреждений, которые стремились достичь послушания детей и приучить их к коллективным действиям. Отдать ребенка в детский сад было равносильно, как принято было говорить, «сдаче чемодана в камеру хранения». Но за место в детском саду или яслях приходилось бороться в силу их дефицитности, а без устройства ребенка женщина

\footnotetext{
${ }^{5}$ Паспорта и система прописки были введены 27 декабря 1932 г.; фотография стала обязательным атрибутом паспорта с октября 1937 г.; тем, кто имел судимость, в паспорте ставилась отметка.
} 
лишалась возможности работать. Модель семьи с обоими работающими родителями стала практически повсеместным условием как социализации, так и выживания.

Этот период можно назвать временем укрепления двойной морали и новой волны доминирования мужчин над женщинами, впоследствии усилившейся после окончания Второй мировой войны. Дефицит и распределительная система делали свое дело, заставляя идти на любые затраты и компромиссы, и не только в личных целях, но и в решении служебных задач. Принятие нового семейного кодекса в 1936 г., на долгие годы запретившего аборты, породило еще одну грань неравенства между женщинами, разделив их на имеющих «законного мужа» и не имеющих. С позиций нравственных критериев российского социума того времени незамужние женщины из-за общественного осуждения, по сути, лишались права на рождение ребенка. Аборт можно было сделать лишь подпольно, не в медицинском учреждении, что привело к заметному росту материнской смертности. Решение родить вне брака воспринималось как вызов обществу и нередко вынуждало матьодиночку менять место жительства, придумывая легенду для новых соседей. Налицо двойственность процесса эмансипации советских женщин: включенность в социальную жизнь, в процесс производства, возможность быть признанной коллективом, руководящими органами, иметь шанс карьерного роста могли быть растоптаны унизительным вмешательством партийных органов, профсоюзных вождей, осуждением товарищей по работе из-за внебрачной беременности или жалобы в партком «законной жены». Фактическое гендерное неравенство оказывалось сильнее прокламируемого равенства мужчин и женщин. Это не было только убеждением в незыблемости половых различий. Как отмечает О.А. Воронина, «В результате в СССР, на мой взгляд, возник специфический тип традиционной гендерной системы - советский патриархат, при котором основным механизмом дискриминации женщин являлись не мужчины как группа, а государство... Именно в «переподчинении» женщины от мужа - государству и кроется глубинный смысл советской гендерной политики. Разумеется, такое отчуждение мужских прав на женщину в пользу государства не только не способствует редукции патриархальных принципов социального устройства, но и усиливает их» (Воронина 2018: 42).

В оценках официальных лиц гендерные различия стирались, поскольку и мужчина и женщина идентифицировались как работник. В этом отношении характерно высказывание И.В. Сталина в 1935 г. на приеме колхозниц-ударниц свекловичных полей руководителями партии и правительства: «Только колхозная жизнь, - говорил Сталин, - могла сделать труд делом почета, только она могла породить настоящих героинь-женщин в деревне. Только колхозная жизнь могла уничтожить неравенство и поставить женщину на ноги. Это вы сами хорошо знаете. Колхоз ввел трудодень. А что такое трудодень? Кто больше трудодней выработал, тот больше и заработал... Трудоднями колхоз освободил женщину и сделал ее самостоятельной» (Цит. по: (Лаптев 1946 4:28)).

Великая отечественная война унесла жизни миллионов советских граждан, из которых людские потери России составили 48,5\%, примерно 13 млн человек (Рыбаковский 2001: 92). Юность сотен тысяч девушек пришлась на годы войны. Далеко не все из них смогли стать женами, матерями. «Дефицит» мужчин привел к фактическому двоеженству или даже многоженству, причем общество стало более лояльно относиться к этим фактам. 
Все более явным становилось предпочтение мужчины при назначении на должность руководителя не только крупного, но и небольшого коллектива, при трудоустройстве, зачислении в вуз, предоставлении стипендии.

Завершение предвоенного периода ознаменовалось введением еще одной меры воздействия на брачное и репродуктивное поведение советских граждан: 21 ноября 1941 г. вышел Указ «О налоге на холостяков, одиноких и бездетных граждан СССР». В паспорте появилась графа «Семейное положение», где указывались сведения о супруге, время и место регистрации брака. Налог взимался с момента замужества/женитьбы. Существенное воздействие оказало законодательство о семье и браке 1944 г.: 8 июля 1944 г. был принят Указ Президиума Верховного Совета СССР «Об увеличении государственной помощи беременным женщинам, многодетным и одиноким матерям, усилении охраны материнства и детства». Этим же указом устанавливались высшая степень отличия - звание «Матьгероиня», медали «Материнская слава» и «Медаль материнства» ${ }^{6}$, принятые с целью поддержки многодетности. Для усиления негативного отношения к разводам вводилась публичная процедура развода через суд. Устанавливалось признание только официально зарегистрированного брака. Соответственно, женщине нельзя было обращаться в суд с иском об установлении отцовства и о взыскании алиментов, если ребенок родился в незарегистрированном браке. С этого времени в метрике такого ребенка в графе «отец» стал проставляться прочерк как метка «безотцовщины». Это постановление не касалось детей, родившихся вне брака, если один из родителей не вернулся с войны ${ }^{7}$.

Все принимаемые законодательные акты влияли на изменения в составе семей, на судьбы мужчин и женщин. Регистрация брака рассматривалась как акт, осуществляемый в первую очередь в интересах государства. Оценивая роль Указа 1944 г., А.Г. Вишневский подчеркивает, что это была попытка противостоять «дестабилизации брачных отношений в разоренной войной России в условиях резко повысившейся социальной и географической мобильности десятков миллионов, поднятых войной со своих мест людей, и длительного разрыва гендерных связей» (Вишневский 2006: 91). С этим выводом трудно не согласиться, однако нельзя упускать из вида и моральный ущерб, понесенный матерями-одиночками и детьми, которые были лишены сведений об отце.

\section{ЭВОЛЮЦИЯ СЕМЬИ В ПОСЛЕВОЕННЫЙ ПЕРИОД}

Обобщая характеристику послевоенного периода, А.Г. Вишневский пишет: «Власти очень скоро научились использовать громкое морализирование в патриархально семейном духе, что позволило бесцеремонно вмешиваться в жизнь семьи: морализаторскими заклинаниями сопровождались запрет аборта, ограничения разводов, непризнание незарегистрированных

\footnotetext{
6 Звание «Мать-героиня» присваивалось женщине, родившей и воспитавшей 10 детей при возрасте последнего не менее 1 года и при наличии в живых остальных детей. Орден «Материнская слава» был трех степеней - за 9, 8, 7 рожденных и выращенных детей. Медаль материнства была двух степеней: первая степень - за рождение и воспитание 6 детей по достижении младшим возраста 1 года и при условии, что все дети живы; второй степени - за рождение 5 детей при тех же условиях.

${ }^{7}$ Указ Президиума Верховного совета СССР от 10 ноября 1944 г. « О порядке признания фактических брачных правоотношений в случае смерти или пропажи без вести на фронте одного из супругов».
} 
браков, повышенное внимание к «моральному облику» при назначении на «ответственные должности», вмешательство «общественности» в семейные дела, преувеличенное целомудрие официального искусства» (Вишневский 2008b: 12).

Первые послевоенные годы - время массовой миграции, прежде всего, демобилизованных и возвращающихся из эвакуации. К 1948 г. этот процесс в основном завершился (Жиромская 2001: 82-83). Все органы планирования и управления нуждались в актуальных данных о населении, его численности, составе и расселении. Как известно, основным источником данных о семье является перепись населения. Данные, фиксируемые в переписном листе, воссоздают родственные связи между членами семьи, позволяют оценить перспективы рождения новых членов семьи, отделения подросших детей от родительской семьи, делать выводы о ресурсах семьи и ее развитии.

Все европейские страны, участвовавшие и не участвовавшие во Второй мировой войне, провели переписи населения в период 1945-1951 гг., но в СССР этот вопрос не поднимался по многим причинам: недостаток материальных и финансовых ресурсов, нехватка квалифицированных кадров, но главное - из-за нежелания И.В. Сталина раскрыть истинные масштабы людских потерь. Органы исполнительной власти были вынуждены руководствоваться той оценкой, которая была дана И.В. Сталиным в интервью корреспонденту «Правды» относительно речи г. Черчилля: «В результате немецкого вторжения Советский Союз безвозвратно потерял в боях с немцами, а также благодаря немецкой оккупации и угону советских людей на немецкую каторгу около семи миллионов человек» (Интервью тов. И.В. Сталина... 1946: 3). Последующий расчет людских потерь для СССР методом демографического баланса дал цифру почти в четыре раза большую: 26,6 - 27 млн человек (Андреев, Дарский, Харькова 1993). После смерти И.В. Сталина (5 марта 1953 г.) подготовка к переписи населения стала реальным делом, но провести Всесоюзную перепись населения удалось только в январе 1959 г. Итоги переписи опубликованы в 15 томах (по числу союзных республик), кроме того, был издан сводный том итогов переписи по СССР. Хотя данные переписи населения 1959 г. отстояли от времени окончания войны почти на 15 лет, все равно цифры показали наличие значительного женского перевеса, т. е. преобладания женщин над численностью мужчин, особенно в когорте 1905-1924 годов рождения. По итогам переписи населения 1959 г. на 1000 мужчин в России приходилось 1243 женщины. Эта цифра, катастрофическая по своей сути, не отражает той глубины диспропорции населения по полу, которая была на момент окончания Великой отечественной войны и войны с Японией. За прошедшие после войны годы соотношение полов несколько выровнялось, тем не менее диспропорция структуры по полу продолжала влиять на брачность, разводимость и рождаемость.

Поскольку посемейная разработка материалов переписи 1959 г. включала только распределение семей по размеру (таблица 2), нельзя увидеть семейную структуру по данным первой послевоенной переписи. По сравнению с данными переписи 1926 г. меньше стало крупных семей, включающих 5 и более человек. Уменьшение размера семьи происходило под влиянием как упрощения состава семей, так и снижения рождаемости. Если первый процесс мог инспирироваться и контролироваться государством через жилищное строительство, то вывод о снижении рождаемости стал в какой-то степени неожиданностью для руководства страны (Волков 2014: 524-527). Во всяком случае, 
снижение рождаемости не сразу стало предметом дискурса и попыток повлиять на этот процесс.

Что касается жилищного строительства, то оно началось в крупных городах с середины 1950-х годов, включая «самстрой». Массовое жилищное строительство развернулось несколько позже, в 1960-1970-е годы. Возможность проживания в отдельной квартире открыла новый этап в модернизации российской семьи, создав условия для нуклеаризации семей. Улучшился моральный климат в обществе: исчезли неприязненные соседские отношения; не стало повода для склок, не нужно было устанавливать очередь уборки в местах общего пользования, уносить из кухни кастрюли и др. В 1960-1970-е годы отделение молодых семей от родительской семьи стало, пожалуй, главным фактором уменьшения размера семьи. Вторым фактором стало снижение рождаемости. Эта тенденция давно была замечена демографами и социологами, но только в 1968 г. Отделу статистики населения НИИ ЦСУ СССР удалось начать исследования репродуктивного поведения населения, планирования семьи, выявления идеального, желаемого и ожидаемого числа детей в семье (Волков 2014). Итоги этой работы детально проанализированы и опубликованы (Белова 1975; Белова, Дарский 1972).

И нуклеаризация семей, и снижение рождаемости приводили к уменьшению размера семьи. Это подтверждают данные таблицы 2. Крупные семьи по 5-6 и более человек после 1979 г. становятся редкостью для городов: если в 1926 г. таких семей было 33\%, то в 1959г. - 20,4\%, а в 1979 г. - всего лишь 11\%. Тенденция уменьшения размера семьи продолжилась и в постсоветский период, прежде всего под влиянием снижения рождаемости: в 1990 г. коэффициент суммарной рождаемости для городского населения составлял 1,698, а в 2000г. - 1,089 ребенка (Росстат 2019: 45). Характерно, что крупные семьи (5 и более человек) по данным постсоветских переписей населения сохранили свои позиции в структуре городских семей (10-11\%).

Таблица 2. Распределение городских семей/ частных домохозяйств по числу членов, $\%$

\begin{tabular}{c|c|c|r|r|r|c}
\hline Год & \multicolumn{5}{|c|}{ Семьи, состоящие из } & Средний размер \\
\cline { 2 - 5 } & 2 человек & 3 человек & 4 человек & 5 человек & 6 и более человек & семьи, человек \\
\hline 1926 & 21,6 & 24,3 & 21,1 & 14,7 & 18,3 & 4,0 \\
1959 & 27,2 & 29,3 & 23,1 & 12,1 & 8,3 & 3,5 \\
1970 & 26,0 & 31,5 & 26,8 & 10,7 & 5,0 & 3,4 \\
1979 & 30,5 & 33,9 & 24,6 & 7,8 & 3,2 & 3,2 \\
1989 & 34,2 & 28,0 & 25,2 & $12,5(5$ и более) & - & 3,2 \\
2002 & 35,7 & 32,2 & 21,7 & 6,7 & 3,8 & 3,1 \\
2010 & 39,2 & 31,7 & 19,2 & 6,4 & 3,5 & 3,1 \\
\hline
\end{tabular}

Источники: (ЦСУ СССР 1928а: 105; 1962: 111; 1963: 438-439; 1974: 206-207; Poсcтат 2002; 2010).

Данные таблицы 2 не позволяют проследить изменения в составе семьи, в распространенности семей с полной брачной парой с одним или несколькими детьми и их распределении по числу детей. Очевидно, что такие семьи могут войти в любую группу, кроме семей, состоящих из двух человек. Какова доля полных семей с одним и более несовершеннолетними детьми в каждой из последующих групп, можно только предполагать. А.И. Антонов, ссылаясь на статистический сборник «Семья в России. 2008» (Росстат 2008), отмечает, что «среди частных домохозяйств семейные пары с детьми 
составляют 30\%, без детей - 25,8\%» (Антонов, Борисов 2011: 118). По нашим расчетам, основанным на тех же данных, семейные пары с детьми на тот же период составляли 35\% частных домохозяйств (Росстат 2008: 30). Если скорректировать на возможную наличность прочих родственников, то долю таких семей в структуре частных домохозяйств можно оценить в интервале 30-33\%. По данным всероссийских переписей населения 2002 и 2010 г. доля семей с детьми в возрасте до 18 лет среди семей с супружеской парой в 2002 г. составила 53,7\%, в 2010 г. - 46,4\% (Росстат 2010). Расхождения с вышеприведенными цифрами объясняются различиями в методике расчета показателей. Цифра из сборника «Семья в России» более точно отражает представительство семей с одной брачной парой и с несовершеннолетними детьми в структуре семей и может быть принята за основу.

Очевидно, что пропорции, которые были выявлены переписью 2002 г., совсем не обязательны для 2020 г. Все процессы, происходящие в семье, подвержены воздействию множества факторов, причем действие каждого из них реализуется нелинейно и не одномоментно. По данным таблицы 2 можно предполагать, что на изменение размера семьи влияло как упрощение состава семьи, так и нарастание малодетности. К настоящему времени и тот и другой факторы изменили свое проявление. Процесс нуклеаризации сменился процессом денуклеаризации: доля нуклеарных семей среди домохозяйств из 2 и более человек составляла в 1970 г. 75,8 \%, в 1989г. 81,1\%, тогда как в 2002 г. 70,2\%, в 2010 г. 67,5 \% (Елисеева, Васильева 2014: 37). Изменилась роль и второго фактора - рождаемости: если в 1970-1990-е и первой половине 2000-х годов этот фактор приводил к уменьшению размера семьи в силу доминирования однодетности и откладывания рождений, то начиная с 2007 г. рождаемость стала приводить к росту числа членов семьи вследствие повышения рождений вторых детей. К настоящему времени установился паритет между рождением первых и вторых детей: и тот и другой типы в современном распределении детей по очередности рождений составляют по $40 \%{ }^{8}$.

\section{СОсТАВ СЕМЫИ}

Сопоставление данных переписей по наличию и числу брачных пар показывает, что процесс нуклеаризации семей продолжался: увеличивалась доля семей с брачной парой и неполных семей без других родственников (таблица 3). Существенно возросла доля прочих семей, что в некоторой степени объясняется как внешней, так и внутренней миграцией в постперестроечный период (де Танги 2012). В обоих случаях дети оказывались не с родителями, а с другими родственниками (бабушками, тетями, дядями, братьями, сестрами) или с не родственниками, т. е. формировались домохозяйства без родительского ядра.

Данные о семейной структуре вызывают больше вопросов, нежели распределение семей по размеру, во-первых, из-за перехода в постперестроечный период от такой единицы учета, как семья, к учету частных домохозяйств; во-вторых, из-за сохраняющегося объединения брачных пар без детей с брачными парами с детьми; в-третьих, из-за изменения государственного устройства. Семьи с одной брачной парой доминируют.

\footnotetext{
${ }^{8}$ К сожалению, в официальных статистических изданиях не публикуются распределения родившихся по очередности рождений.
} 
Растет доля неполных семей, причем для этой категории характерно стремление жить с другими родственниками.

Таблица 3. Семейная структура населения России по данным переписей населения, \% к итогу

\begin{tabular}{l|r|r|r|r}
\hline Состав семьи & 1970 & 1989 & 2002 & 2010 \\
\hline Одна брачная пара с детьми и без детей & 63,3 & 67,9 & $68,5 *$ & 52,1 \\
Одна брачная пара с детьми и без детей и другими родственниками & 15,7 & 11,5 & & 13,9 \\
Две и более брачные пары с детьми и без детей с другими & 3,1 & 3,3 & 3,3 & 3,4 \\
родственниками или без них & 12,5 & 13,2 & 15,3 & 15,4 \\
Мать (отец) с детьми & 3,5 & 2,0 & 6,4 & 5,6 \\
Мать (отец) с детьми и другими родственниками & 1,9 & 2,1 & 6,5 & 9,6 \\
Прочие семьи & & & \\
\hline
\end{tabular}

Источники: (Росстат 2002; 2010).

Примечание: *-В указанном источнике иифра приведена без разделения на подгруппы.

Разобраться с составом группы, включающей одну брачную пару, позволяют данные массового выборочного обследования «Комплексное обследование условий жизни населения» (КОУЖ), проводимого Росстатом раз в 2 года. Объем выборки составляет около 60 тыс. человек. Структура домохозяйств по данным КОУЖ представлена в таблице 4.

\section{Таблица 4. Структура домохозяйств России, 2018}

\begin{tabular}{lr}
\hline Тип домохозяйства & \% к итогу \\
\hline Домохозяиство из одного лица & 33,8 \\
Домохозяйство из матери (отца) с ребенком (детьми) без других родственников & 5,0 \\
Домохозяйство из матери (отца) с ребенком (детьми) с другими родственниками & 2,0 \\
Домохозяйство из одной супружеской пары без ребенка и без других родственников & 23,3 \\
Домохозяйство из одной супружеской пары без ребенка и с другими родственниками & 6,9 \\
Домохозяйство из одной супружеской пары с ребенком (детьми) & 20,1 \\
Домохозяйство из двух и более супружеских пар (с детьми или без) & 1,0 \\
Прочие домохозяйства & 8,0 \\
Всего & 100,0 \\
\hline
\end{tabular}

Источник: Составлено автором по данным КОУЖ-2018.

URL: https://rosstat.gov.ru/free_doc/new_site/KOUZ18/index.html

По данным таблицы 4 доля одиночек выросла по сравнению с Всероссийской переписью населения (ВНП) 2010 г.: 33,8\% против 26\%. Конечно, цифры выборочного обследования должны восприниматься с учетом ошибки выборки, но в любом случае рост распространенности домохозяйств, состоящих из одного человека, налицо. Окончательные выводы будем делать после публикации данных ВПН-2020. Что ценно в этой группировке, так это возможность разделения брачных пар без детей и брачных пар с детьми. В структуре выборки КОУЖ брачные пары без детей распространены больше, нежели брачные пары с детьми. Объяснение этого требует привлечения данных о возрасте супругов, чтобы отделить “empty nests" от брачных пар с женщиной в фертильном возрасте. В эту же группу входят бездетные брачные пары, доля которых растет (долю бездетных оценивают на уровне $10 \%$ брачных пар), а также и те, кто сознательно отказался от рождения детей (child free families). Превышение брачных пар без детей над имеющими детей свидетельствует о снижении демографического (воспроизводственного) потенциала России. 
При переходе от структуры домохозяйств к рассмотрению семейной структуры приходится объединять в одну группу семьи с одной брачной парой с детьми и без детей, чтобы сравнить с данными ВПН-2010 (таблица 5).

Таблица 5. Семейная структура населения России, \% к итогу

\begin{tabular}{|c|c|c|}
\hline Состав семьи & 2010 & 2018 \\
\hline Одна брачная пара с детьми и без детей & 52,1 & 60,2 \\
\hline Одна брачная пара с детьми и без детей и другими родственниками & 13,9 & 15,6 \\
\hline Две и более брачные пары с детьми и без детей с другими родственниками или без них & 3,4 & 1,5 \\
\hline Мать (отец) с детьми & 15,4 & 7,6 \\
\hline Мать (отец) с детьми и другими родственниками & 5,6 & 3,0 \\
\hline Прочие семьи & 9,6 & 12,1 \\
\hline
\end{tabular}

Данные таблицы 5 отражают рост доли семей с одной брачной парой как продолжения нуклеаризации семей. В данных КОУЖ существенно меньше, нежели в данных ВПН-2010, представлены неполные семьи: 10,6\% по сравнению с $21 \%$. Столь значительное сокращения присутствия этого типа сигнализирует о наличии определенного смещения выборки. Увеличение доли прочих семей, в которых часто имеются дети, но нет родителей, может рассматриваться как еще одно подтверждение снижения воспроизводственного потенциала российских семей. Семья «родители-дети» стала нуклеарной и малодетной, с 1-2 детьми. По своей представительности этот тип уступает семьям с одной брачной парой без детей, что не отвечает его статусу «основной семьи»

В переписном листе предстоящей переписи населения 2020 г. (в связи с пандемией ее проведение сдвинуто на 2021 г.) предусмотрены те же самые категории брачного состояния, которые регистрировались в переписи 2010 г. и отчасти в переписи 2002 г. Это даст возможность выявить динамику каждой из категорий, в частности изменение доли состоящих в официально зарегистрированном браке. Сравнение данных всероссийских переписей населения 2002 и 2010 г. свидетельствует о снижении этого показателя с 91,0\% (в 2002 г.) до $87,2 \%$ (в 2010 г.) . $^{9}$

\section{РАЗНООБРАЗИЕ И МОДИФИКАЦИЯ ТИПОВ ОСНОВНОЙ СЕМЬИ}

Сокращение доли семей, которые традиционно воспринимаются как основные (родители несовершеннолетние дети) сочетается с другими тенденциями, усиливающими хрупкость семьи, ее уязвимость. Текущие незаметные изменения, постепенно накапливаясь, становятся все более заметными. Подчас семья трансформируется настолько сильно, что возникает реакция отторжения («нет, это не семья», «кризис семьи», «семья рушится») (Антонов, Борисов 1990; Антонов 2016; Синельников 2015 и др.). Семья «родители-дети» может сформироваться в результате развода и повторного брака, в результате создания брачного союза после овдовения. Поэтому все больше внимания исследователи уделяют

\footnotetext{
9 Заметим, что гражданский брак не может рассматриваться в дихотомии с церковным, как это делает, например (Синельников 2015). Деление браков на церковные и нецерковные с позиций выделения официально зарегистрированных браков не имеет смысла, поскольку в России церковный обряд предполагает официальную регистрацию брака. 
отношениям "stepparents" между собой и их отношениям с детьми (с ребенком), выделяя роли "stepfather" и "stepmother" (Berger, McLanahan 2015: 212-218). Нарастание сложности взаимоотношений с родителями может возникнуть у ребенка, рожденного суррогатной матерью, а также у усыновленных детей.

Основные семьи порождают разнообразные модификации семьи (Захаров 2007). Рассмотрим те из них, которые уже обозначились к настоящему времени (таблица 6).

Таблица 6. Современные модификации основной семьи

\begin{tabular}{|c|c|c|c|c|c|}
\hline Основание для & \multicolumn{5}{|c|}{ Брачная пара с одним и более несовершеннолетними детьми } \\
\hline $\begin{array}{l}\text { Признаки, } \\
\text { входящие в } \\
\text { определение } \\
\text { семьи: кровно- } \\
\text { родственные } \\
\text { связи, общность } \\
\text { бюджета и } \\
\text { жилища }\end{array}$ & $\begin{array}{l}\text { Присутствуют } \\
\text { все признаки } \\
\text { семьи }\end{array}$ & $\begin{array}{l}\text { Нет } \\
\text { общего } \\
\text { бюджета }\end{array}$ & $\begin{array}{l}\text { Нет постоянного } \\
\text { совместного } \\
\text { проживания } \\
\text { (гостевой брак) }\end{array}$ & $\begin{array}{l}\text { Присутствуют } \\
\text { только } \\
\text { признаки } \\
\text { родства и } \\
\text { свойства } \\
\text { (гостевой } \\
\text { брак при } \\
\text { раздельном } \\
\text { бюджете) }\end{array}$ & $\begin{array}{l}\text { Отсутствуют } \\
\text { кровно- } \\
\text { родственные } \\
\text { связи (могут } \\
\text { отсутствовать } \\
\text { и другие } \\
\text { традиционные } \\
\text { признаки } \\
\text { семьи) }\end{array}$ \\
\hline $\begin{array}{l}\text { Характер } \\
\text { отношений } \\
\text { между супругами } \\
\text { Характер } \\
\text { внутрисемейных } \\
\text { отношений }\end{array}$ & Патриархальная & Супружеская & Детоцентристская & Амбива & гентная \\
\hline
\end{tabular}

В этой типологии не фокусируется деление браков на официально зарегистрированные и незарегистрированные, т. е. гражданские браки. В категориях брачного состояния в постсоветских переписях населения эти браки разделены. Но на существовании брака как такового регистрация не должна сказываться, поэтому при проведении переписей всегда регистраторы исходили из фактического состояния в браке. В определенной степени такая традиция возникла как отголосок свобод, которые декларировались в первое десятилетие советской власти. Вдобавок это соответствует пониманию переписи как самоопределения граждан: при переписи никто не имеет права сопоставлять ответы с документами. Это касается не только брачного состояния, но и числа рожденных детей, образования, занятия и др. Детализация вариантов ответов может быть различной, но всегда основанной на самооценке респондента. В постсоветских переписях населения 2002 и 2010 г. брачное состояние включает следующие категории: состою в официально зарегистрированном браке; состою в незарегистрированном браке, разведен/разведена, разошелся/разошлась (последняя категория появилась в переписном листе 2010 г.); вдовец/вдова; никогда не состоял(а) в браке. Распространенность гражданских браков приводит к снижению информативности текущей статистики брачности. Неким паллиативом становятся данные о регистрации детей, родившихся вне зарегистрированного брака, обоими родителями (Вишневский 2019: 213). Если в 1992 г. среди рожденных вне брака 41,4\% были зарегистрированы по заявлению обоих родителей, то в 2018 - 50,7\% (максимум принадлежит 2016 г. - 52,9\%) (Росстат 2019: 67).

Права и обязанности, связанные с сексуальной жизнью и производством потомства, а также с проблемами имущества и наследства, в настоящее время дает только официально 
зарегистрированный брак. Так что в крупных, особенно в столичных, городах, где уровень жизни выше среднероссийского и есть, что оставить наследникам, доля родившихся в зарегистрированном браке не снижается, а напротив, растет.

Решение о регистрации брака не всегда легко дается. Одной из причин отказа от регистрации брака можно считать усилившееся среди молодежи понимание брака как глубоко интимного события. Такие пары предпочитают «не выставляться» и либо не регистрируют брак, либо не ставят в известность об этом событии родственников и друзей (Гуттенбюль-Крейг 2007: 90).

Для изучения стабильности брака важно выделение браков по очередности или хотя бы разделение данных о вступающих в первый брак и повторный. К сожалению, отечественная статистика публикует распределение браков по возрасту жениха/невесты, а также совместное распределение по возрастам брачующихся, не выделяя первобрачных.

На основе брака как устойчивого и взаимноответственного союза гетерогенных супругов возникает семья и здесь возможны различные варианты или подтипы семей (таблица 6). Прежде всего это семьи, отвечающие классическому определению семьи - с наличием кровного родства, с общим жилищем и бюджетом. Но в современной семье некоторые из этих признаков (и даже все признаки) могут отсутствовать. Дети могут быть не кровными, а усыновленными, да и остальных признаков может не быть. Как пишет Р. Йенсен, это семьи, где отношения строятся по принципу: «Мы делим ложе и стол, но совсем не обязательно чековые книжки и мнения» (Йенсен 2002: 195). В современной России раздельный бюджет также не является редкостью.

Семья может не иметь постоянного общего жилища (гостевой брак). Такой тип семьи может возникнуть в силу особенностей здоровья супругов (как в случае брака А.П. Чехова и О.Л. Книппер, когда было принято решение после женитьбы «оставить все, как прежде», он - в Ялте, она - в Москве, прикрываясь фразами о «невозможности ежедневно выносить семейное счастье»). С распространением цифровизации к раздельной жизни может подтолкнуть характер занятости: при наличии разных временных поясов с работодателем или при иных условиях удаленной занятости. При этом семейная жизнь организуется повседневно как раздельная, а совместная - от уик-энда до уик-энда. В развитых странах весомой причиной раздельной жизни супругов становится индивидуализация, стремление к независимости, к сохранению собственного стиля жизни. Современные коммуникационные технологии позволяют поддерживать постоянный контакт друг с другом. Живя раздельно, супруги и дети не перестают быть семьей: у них общие интересы, общие планы; возможен частично или полностью общий бюджет. Их связывает взаимное чувство ответственности (и любви). Границы семьи расширяются, но семья не исчезает, она трансформируется в соответствии с новыми условиями жизни. Living apart together (LAT) нередко рассматривается как «ключ к счастливому браку» (Гурко 2017). В качестве примеров вынужденной раздельной жизни супругов Т.А. Гурко называет также период службы в армии или нахождения в заключении (Гурко 2017).

Семья живет не в изоляции, большое влияние оказывает ее окружение: родственное, соседское, дружеское. Причем значимость этого окружения меняется. По данным О.Н. Бурмыкиной, 10 лет назад социально значимыми были родственники по материнской 
линии, сейчас доминирующим типом общения стал комбинированный тип, включающий как кровных, так и некровных родственников и партнеров (Бурмыкина 2018: 36-38). Это еще одно подтверждение расширения границ семьи, трансформации семьи в сетевую структуру (Елисеева 2018a). Последний подтип в таблице 6 включает брачную пару и приемных детей (одного или нескольких) при наличии или отсутствии остальных признаков семьи.

Так что варианты сочетания традиционных признаков семьи способны дать не менее четырех подтипов. Вероятность реализации каждого из вариантов различна, по крайней мере, в настоящее время: от массовости первого подтипа до сравнительно редкого появления остальных подтипов. Но во всех вариантах модификации семьи нет сомнений это семья, трансформирующаяся, не похожая на традиционную, но остающаяся «первичной ячейкой общества».

Последующие основания типологии в таблице 6 не связаны с первым, хотя их контент также проистекает из традиционного понимания семьи.

Второе основание типологии семей основано на характере супружеских отношений, что приводит к трем типам семей, достаточно изученным (Гурко 2010; Голод 1998; Клецин 2003; Захаров 2016). Муж и жена как первичное ядро основной семьи, как ее исток могут образовывать традиционную патриархатную семью, в которой решения вырабатываются и принимаются главой семьи (мужем) и не обсуждаются, а выполняются; воспитывается беспрекословное подчинение младших старшим. Обязанности по ведению семейного хозяйства подразделяются на мужские и женские, причем для женщины семейные обязанности считаются главными.

Может сформироваться эгалитарная семья, основанная на демократических принципах равных прав и ответственности супругов. В семье этого типа утверждается значимость внесемейной роли женщины. Эти принципы транслируются от родителей детям и формируют их заинтересованное участие в семейных делах (Голод 1998; Клецин 2003). Еще одним подтипом являются амбивалентные семьи, в которых поведение мужа и жены, а также детей неустойчиво, они не придерживаются определенных правил, живут в ситуативном режиме, при возникновении одних и тех же задач в разных обстоятельствах могут принимать различные решения, весьма противоречивые. Т.А. Гурко отмечает частую встречаемость этого типа отношений в повторных браках и не столько между супругами, сколько каждого из них по отношению к ребенку от предыдущего брака (Гурко 2020: 70). Н.А. Нечаева делает вывод о переходно-амбивалентных отношениях, обращая внимание на их широкую распространенность в России (Нечаева 2019: 130).

Третье основание типологии семей - это внутрисемейные отношения, включающие как отношения между супругами, так и отношения матери с детьми, отца с детьми и отношения между детьми. Характер внутрисемейных отношений формирует «климат в семье» - оптимальный, если он обеспечивает необходимый баланс между автономией каждого члена семьи и семейной интеграцией. По внутрисемейным отношениям семьи можно подразделить на патриархатные (традиционные), детоцентристские, супружеские, амбивалентные. Очевидна близость этой классификации с предыдущей. В патриархатной семье роль главы семьи принимает на себя мужчина, задавая жесткую иерархию отношений 
«по вертикали». В супружеской семье все решения принимаются отцом и матерью совместно, доминируют отношения «по горизонтали». Степень близости ребенка с отцом и с матерью, как показывают исследования О.Н. Бурмыкиной, различаются довольно существенно. Личность матери ребенок воспринимает как идентичную ему самому, а личность отца, при несомненной близости, отодвигается на гораздо большую дистанцию (Бурмыкина 2015: 201). В качестве «приметы времени» можно считать расширяющееся осознание ценности родительства молодыми мужчинами (Чикалова 2016).

Различия в структуре и содержании внутрисемейных связей в основной семье возникают под влиянием числа детей в семье. При этом обязательно выделение брачных пар с одним ребенком и с двумя и более детьми. Последний тип, кроме отношений между супругами и каждого из них с детьми, включает отношения между детьми. Эти отношения способствуют ускорению социализации детей, их физическому и умственному развитию за счет влияния на младших старших детей, охранительному поведению старших по отношению к младшим. В будущем отношения между сиблингами могут привести либо к сотрудничеству и взаимопомощи, либо к соперничеству и конфликтам из-за имущественных вопросов, распределения обязанностей по уходу за тяжело больным членом семьи и др. В детоцентристской семье идеи и потребности осознаются детьми и транслируются родителям, не исключая родительских инициатив, по принципу как «снизу вверх», так и «сверху вниз».

Уже в 1974 г. Э. Россет писал: «О многодетной семье сейчас следует говорить в прошедшем времени. Этот тип изжил себя. Сегодня идет борьба не за четвертого и пятого ребенка, а за второго и третьего ребенка. Чтобы выиграть эту борьбу, необходимо пустить в ход стимулы - и материальные и моральные» (Россет 1974: 52). Но, чтобы сформировать систему стимулов и сделать ее эффективным инструментом демографической политики, необходимы рандомизированные выборочные обследования с использованием гибких методик, созданных командой демографов, социологов, психологов, экономистов, антропологов, юристов. Это дорогостоящая работа принесет больше результатов, нежели программы по возвращению соотечественников или «дальневосточный гектар» и др., которые производят впечатление поиска вслепую (по принципу «а вдруг сработает»). Россия малодетная страна с 1-2 детьми в семье. Обсуждать модель трехдетной семьи преждевременно в период неопределенности и падения экономики вследствие пандемии и других факторов. В России есть некоторый резерв роста рождаемости - это перестройка психологии женщин, решающих сделать аборт. В ряде исследований (Ерофеева 2017: 26; Елисеева 2018b: 214-215) доказано, что сейчас решение об аборте часто принимается женщиной не из-за материальных факторов (низкого дохода, плохих жилищных условий), а из-за неуверенности в партнере. Современный аборт - это в значительной степени проблема нелюбви и отсутствия психологической поддержки со стороны партнера/мужа и родственников. Данное утверждение не отрицает роли материального фактора, а подчеркивает силу воздействия нематериальных факторов. Тема планирования семьи, недопущения незапланированной беременности по-прежнему актуальна для России (Сакевич 2017). Для регионов с плохой экологией, где более высокая доля самопроизвольных абортов, благополучное протекание беременности может возрасти при условии улучшения качества среды обитания - чистого воздуха, высококачественной 
питьевой воды, незагрязненной вредными отходами почвы. В целом стереотип, сложившийся в советское время «одна семья - один ребенок» трансформировался в убеждение «пусть у меня будет один ребенок, но у него будет все».

\section{ЗАКЛЮЧЕНИЕ}

Краткий обзор предыстории формирования современной семьи подтвердил зависимость эволюции российской семьи от условий жизни и тех рамок поведения, которые устанавливает власть и общество. Ослабление официальных ограничений наряду с изменением социальных норм привело к необычайному множеству типов семей, в котором проявились «признаки новейших перемен, которые затронули все звенья процесса формирования семьи, все стороны ее жизнедеятельности» (Вишневский 2019: 216). Современная российская семья, даже если рассматривать только основные семьи, т. е. семьи с полной брачной парой и несовершеннолетними детьми, по характеру отношений между супругами, по репродуктивному поведению отражает, по словам А.Г. Вишневского, «небывалую диверсификацию форм демографического и брачно-семейного поведения, что резко контрастирует с небольшим числом стандартных, унифицированных моделей такого поведения в прошлом» (Вишневский 2019: 217). В настоящее время многие демографы и социологи разделяют этот вывод. Первым из отечественных социологов, кто разглядел в изменении конфигурации семьи, неполноте проявления ее классических признаков не кризис и распад семьи, а плюрализацию типов семейных отношений, стал С.И. Голод (19352013). Ему удалось связать этот процесс с пересмотром моральных норм, изменений в рождаемости, растущей продолжительности предстоящей жизни, высокой разводимости и многих других сопряженных процессов. Человечество вступило в период поиска новых конструкций «первичной ячейки общества». С.И. Голод подчеркивал непреложность семьи как способа организации жизни людей, то что семья была, есть и будет. Но какой она будет, сохранятся ли магистральные параметры ее модернизации: будут ли характерны для семьи нуклеарность, расширение профессионально занятых женщин (обоюдная карьера жены и мужа), сознательно планируемая малодетность, эгалитарность в принятии решений, относительно высокая разводимость, сложившееся супружество, в котором нарастание автономизации личности гармонично сочетается с усилением потребности в интимности, т. е. взаимопонимании - трудно дать однозначный ответ на все эти вопросы (Голод 1998; 2005). Очевидно лишь то, что семья - это продукт социальной эволюции и она будет изменяться с изменением общества. Российская семья впитывает те тренды, которые возникают в развитых странах (при временных лагах и специфике проявления, но по существу имеющих ту же сущность). Стремление детей к ранней независимости и отделению от родительской семьи сочетается с потребностью вернуться к родителям, если что-то не сложилось в личной жизни. Возник новый термин «boomerang children», который чаше относится к мужчинам. В 2016 г. в Великобритании 25\% лиц в возрасте 20-34 года жили со своими родителями, что на 16 процентных пунктов больше, чем в 1996 г. (Burton 2020: 2). Тенденции возвращения в родительскую семью проявились и в России в денуклеаризации семей. 
С позиций воспроизводства и проводимой демографической политики главная роль должна принадлежать двухпоколенной семье «родители-дети», трактуемой как «основная семья». Этот тип в настоящее время составляет, по данным КОУЖ, пятую часть частных домохозяйств, что ниже представительства семей с полной брачной парой, но без детей. Причем распространенность таких семей сокращается не только в России. В докладе ОЭСР "The Future of Families to 2030" отмечается, что результатом 10-летнего периода трансформации семьи стало то, что традиционных (т. е. основных) семей, включающих брачные пары с детьми, становится все меньше, тогда как разведенных, сожителей, семей с одним родителем, гомосексуальных семей становится все больше (OECD 2011: 7) .

Отход от исключительного понимания семьи как триединства кровного родства, общего бюджета и жилища приводит к трансформациям семьи, отвечающим новым потребностям людей. Разнообразие семейного ландшафта (более раннее отделение совершеннолетних детей от родительской семьи, выбор между одиночеством и супружеством, бездетностью и наличием детей и др.) стало возможным в условиях преодоления дефицита товаров и услуг. Изменения в структуре российских семей не отменили пока что ролевого доминирования семьи, состоящей из брачной пары с несовершеннолетними детьми. Этот тип можно считать основным типом семьи в силу его роли в выполнении репродуктивной, социальной и экономической функций. Возрастает разнообразие основных семей по традиционным признакам семьи, а также по характеру отношений между супругами и внутрисемейных отношений. Главенство материальных условий как основы стабильности семьи и прочности брака сменяется первостепенным значением любви и взаимной ответственности.

В России, как показывает сравнение данных всероссийских переписей населения, процент брачных пар с детьми до 18 лет тоже сокращается (Елисеева, Васильева 2014). Так что в эволюции семьи наметился поворот в сторону увеличения семейных ячеек нетрадиционного состава.

Современное российское общество сохраняет внутреннюю амбивалентность, его нельзя характеризовать как сугубо традиционное, но в полной мере оно не является и обществом модерна. Рано признавать свободу массового сознания россиян от заветов патриархальности: шлейф прошлого проникает в настоящее и проявляется в сосуществовании основных (нуклеарных) семей со сложными многопоколенными семьями, бездетных с многодетными, эгалитарных семей и семей с явным проявлением патриархальности. Российская семья продолжает переживать процесс модернизации, и этот путь нелинейный, с развилками и петлями возвратности. Дальнейшие исследования в области демографии и социологии семьи, необходимые для понимания происходящих изменений и разработки демографической и семейной политики, требуют совершенствования российской статистики населения, проведения целевых обследований, активного использования имеющихся общероссийских баз данных (КОУЖ, РМЭЗ и др.). Всех отечественных исследователей не покидает надежда на успешное проведение всероссийской переписи населения в условиях продолжающейся пандемии. 


\section{ЛИТЕРАТУРА}

Андреев Е.М., Дарский Л.Е., Харькова Т.Л. (1993). Население Советского Союза, 19221991. М.: Наука.

Андреев Е.М., Дарский Л.Е., Харькова Т.Л. (1998). Демографическая история России. 1927-1959. М.: Информатика.

Антонов А.И. (2016). Кризис фамилистической цивилизации в XXI веке. Экономические стратегии, 1, 40-43.

Антонов А.И., Борисов В.А. (1990). Кризис семьи и пути его преодоления. Научный доклад. М.: Институт социологии АН СССР.

Антонов А.И., Борисов В.А. (2011). Лекциии по демографии. М.: Академический проект; Альма Матер.

Белова В.А. (1975). Число детей в семье. М.: Статистика.

Белова В.А., Дарский Л.Е. (1972). Статистика мнений в изучении рождаемости. М.: Статистика.

Бим-Бад Б.М., Гавров С.И. (2010). Модернизация института семьи. М., Интеллектуальная книга, Новый хронограф.

Бойм С. (2002). Общче места. Мифы повседневной жизни. М.: Новое литературное обозрение.

Борисов В.А. (1976). Перспективы рождаемости. М.: Статистика.

Бурмыкина О.Н. (2015). Межпоколенные взаимодействия в семье: поддержка и социальные сети. В И.И. Елисеева, Аньци Сюй (Ред.), Семья в России и Китае. Проиесс модернизации (сс. 199-232). СПб: Нестор-История.

Бурмыкина О.Н. (2018). Динамика представлений петербургских студентов о семье и межпоколенных отношениях (2007-2017 гг.). Петербургская социология сегодня, 9, 2746.

Васильева Э.К. (1975). Семья и ее функции. М.: Статистика.

Васильева Э.К. (1985). Семья в сочиалистическом обществе. М.: Мысль.

Вишневский А.Г. (2006). Демографическая модернизация России. 1990-2000 М.: Новое издательство.

Вишневский А.Г. (2008а). Эволюция российской семьи. Экология и жизнь, 7. URL: https://elementy.ru/nauchno-populyarnaya_biblioteka/430650/Evolyutsiya_rossiyskoy_semi

Вишневский А.Г. (2008b). Эволюция российской семьи: XX век: от крестьянской семьи к городской. Экология и жизнь, 8. URL: https://elementy.ru/nauchnopopulyarnaya_biblioteka/430651/Evolyutsiya_rossiyskoy_semi_prodolzhenie

Вишневский А.Г., Захаров С.В., Иванова Е.И. (2008). Эволюция российской семьи: современная российская семья. Общая картина. Экология и жизнь, 9. URL: https://elementy.ru/nauchno-populyarnaya_biblioteka/430652/Evolyutsiya_rossiyskoy_semi_

okonchanie

Вишневский А.Г. (2019). Демографическая история и демографическая теория. М.: Изд. дом ВШЭ.

Волков А. Г. (1999). Эволюция российской семьи в XX веке. Мир России, 4, 47-57. 
Волков А.Г. (2014). О некоторых причинах снижения коэффициента рождаемости. Сб. Волков А.Г. Избранные демографические труды (сс. 521-529). М.: Изд. дом Высшей школы экономики.

Волков А.Г., Сороко Е.Л. (1999). Типология семей и домохозяйств в России: развитие и анализ. Вопросы статистики, 5, 40-52.

Воронина О.А. (2018). Гендерная культура в России: традиџии и новаџии. М., ИФ РАН.

Голод С.И. (2005). Что было пороками, стало нормами. М.: Ладомир.

Голод С.И.(1998). Семья и брак: историко-социологический анализ. СПб.: ТОО ТК «Петрополис».

Гуггенбюль-Крейг А. (2007). Брак умер - да здравствует брак! М.: Когито-Центр.

Гурко Т.А. (2010). Теоретические подходы к изучению семьи. М.: Институт социологии PAH.

Гурко Т.А. (2017). Новые семейные формы: тенденции распространения и понятия. Социологические исследования, 11, 99-110.

Гурко Т.А. (2020). Понятие амбивалентности в изучении семейных отношений. Социологические исследования, 2, 63-73.

Декреты советской власти (1957). Т.1. М.: Политиздат.

Елисеева И.И. (2018а). Изменения рождаемости и семьи. В И.И. Елисеева (Ред.), Новая значимость семьи для России и Китая (сс. 65-87). СПб: Реноме.

Елисеева И.И. (2018b). Рождения и нерождения. Петербургская сощиология сегодня, 10, 204-221.

Елисеева И.И., Васильева Э.К. (2014). Основные направления исследования домашних хозяйств по материалам всероссийских переписей населения. Вопросы статистики, 5, $32-40$.

Ерофеева Л.В. (2017). Политика в сфере репродуктивного здоровья в России и международный опыт. Демографический журнал, 2, 22-29.

Жид А. (1990). Возвращение из СССР. М.: Издательство политической литературы.

Жиромская В.М. (Ред.) (2001). Население России в ХХ в. Исторические очерки. T.2. 19401959. М.: РОССПЭН.

Захаров С.В. (2007). Трансформация брачно-партнерских отношений в России: «золотой век» традиционного брака близится к закату? В Т.М. Малевая, О.В. Синявская (Ред.), Родители и дети, мужчины и женщины в семье и обществе. Выпуск 1 (сс. 75-126). М.: НИСП.

Захаров С.В. (2016). Рождаемость в России в период пронатализма. Россия 2016. Ежегодный доклад Франко-российского аналитического иентра Обсерво, Под рук. А. Дюбьена (с. 320-325). М. - Париж: Обсерво. Аналитический центр при франкороссийской торгово-промышленной палате.

Зиновьев А.А.(2019). Советская эпоха. Исповедь отщуепенц̧а. М.: Родина.

Интервью тов. И.В. Сталина с корреспондентом газеты «Правда» относительно речи г. Черчилля (1946). Большевик, 5, март, 1-5.

Йенсен Р. (2002). Общество мечты. СПб: Стокгольмская школа экономики.

Кавелин К.Д. (2019). Мысли и заметки о русской истории. М.: Юрайт. 
Клецин А.А. (2000). Очерк истории социологии семьи. СПб: Петрополис.

Клецин А.А. (2003). Распределение домашних обязанностей между супругами: факты, проблемы, интерпретация. Журнал соџиологии и сочиальной антропологии, VI(2). URL: http://ecsocman.hse.ru/data/557/818/1219/Kletsin.pdf

Лаптев И. (1946). Сила и жизненность колхозного строя. Большевик, 4, 25-37.

Мазур Л.Н. (2015). История российской семьи: проблемы типологии. Bып. 15. Екатеринбург: Издательство Уральского университета.

Миронов Б.Н. (2015). Российская империя: от традиции к модерности. В 3 томах. Т.2. СПб: Издательство «Дмитрий Буланин».

Миронов Б.Н. (2017). Российская революция 1917 года сквозь призму демографической модернизации. Демографическое обозрение, 4(4), 6-58.

Нечаева Н.А. (2019). Гендерная картина мира: к определению понятия и его структуры. Петербургская сочиология сегодня, 12, 114-133.

Нокс А. (2014). Вместе с русской армией. 1914-1917. Дневник военного аттаме. М.: ЗАО Центрполиграф.

Жеребин В.М. (Ред.) (2010). Ресурсный потенциал жизненного цикла семьи. М.: Наука.

Россет Э. (1974). Принципы и проблемы перспективной политики народонаселения. Пер. с польск. В В.С. Стешенко, В.П. Пискунова (Ред.) Демографическая политика (сс. 5268). М.: Статистика.

Росстат (2002). Всероссийская перепись населения 2002 года. URL: http://www.perepis2002.ru/index.html?id=11

Росстат (2008). Семья в России. 2008. URL:http://rosstat.gov.ru/bgd/regl/b08_69/MAIN.htm

Росстат (2010). Всероссийская перепись населения 2010 года. URL: https://rosstat.gov.ru/free_doc/new_site/perepis2010/croc/perepis_itogi1612.htm

Росстат (2019). Демографический ежегодник России. 2019. URL: http://rosstat.gov.ru/bgd/regl/B19_16/MAIN.htm

Рудык О.И. (2015). Эволючия института брака в советском семейном праве (автореф. дисс. на соискание уч. степ. канд. юридич. наук). Нижегородская академия МВД РФ.

Ружже В.Л., Елисеева И.И., Кадибур Т.С. (1983). Структура и функиии семейных групп. М.: Финансы и статистика.

Рыбаковский Л.Л. (2001). Великая Отечественная: людские потери России. Социологические исследования, 6, 85-95.

Сакевич В.И. (2017). Тенденции и проблемы в сфере внутрироссийского регулирования рождаемости в Российской Федерации. Демографический журнал, 2, 14-20.

Салтыков-Щедрин М.Е. (1988). Письма к тетеньке. Собр. соч. в десяти томах. Том седьмой. М.: Издательство «Правда». URL: http://az.lib.ru/s/saltykow_m_e/text_0385.shtml

Синельников А.Б. (2015). Пределы расширения границ семьи и брака. Вестник Московского университета. Серия 18. Социология и политология, 1, 90-108.

де Танги А. (2012). Великая миграция: Россия и россияне после падения железного занавеса. М.: РОССПЭН.

Уэллс Г. (1958). Россия во мәле. М.: Госполитиздат. 
Цеткин К. (1955). Воспоминания о Ленине. М.: Госполитиздат.

ЦСУ СССР (1928а). Всесоюзная перепись населения 1926 года. T.5. М. -Л.

ЦСУ СССР (1928b). Жилищный фонд СССР. Отдел переписей. Вып.6.

ЦСУ СССР (1933). Всесоюзная перепись населения 1926 г. T.55.

ЦСУ СССР (1962). Итоги Всесоюзной переписи населения 1959 года. СССР. М.: Госстатиздат.

ЦСУ СССР (1963). Итоги Всесоюзной переписи населения 1959 года. РСФСР. М.: Госстатиздат.

ЦСУ СССР (1974). Итоги Всесоюзной переписи населения 1970 года. T. VII. М.: Статистика.

Чижова Ж.Г., Шестакова В.Н., Пунина М.А. (2010) Особенности семьи и брака на современном этапе развития общества. Вестник Смоленской медицинской академии, 4, 57-66.

Чикалова Е.А. (2016). Отцовство в фокусе западных социологических и психологических исследований: проблемы и перспективы. Петербургская сочиология сегодня,ㄱ, 201215.

Antsiferov A.N. Bilimovich A.D., Batshev M.O., Ivantsov D.N. (1930). Russian Agriculture during the War. New Haven: Yale University Press.

Berger L.M., McLanahan S. (2015). Income, Relationship Quality and Parenting Associations with Child Development in Two-Parent Families. Journal of Married and Family, 77(4), 996-1015. DOI: https://doi.org/10.1111/jomf.12197

Burton N. (2020). What Future for Family? Families are becoming much more diverse. URL: https://www.psychologytoday.com/ca/blog/hide-and-seek/201708/what-future-the-family

OECD (2011). The Future of Families to 2030. URL: https://www.oecd.org/futures/49093502.pdf 


\title{
THE MAIN FAMILY: BACKGROUND AND PROSPECTS
}

\section{IRINA ELISEEVA}

\begin{abstract}
The article looks at the trajectory of changes in the composition and size of the Russian family in the Soviet period, the transition from the predominance of a complex family to the predominance of a simple family, from having many children to having few. The author focuses on the influence of the state on the Russian family through such an effective instrument as legislation and the radical exclusion of religious institutions from the registration of demographic events. Attention is drawn to the transition from the policy of undermining the family structure in 1918-1920 to the formation of the image of the family as the "basic unit of society", the perception of marriage as an act of state. The impact of legislation on reproductive behavior, especially of unmarried women who are trapped in traditional morality, is emphasized. The significant influence of gender disproportions on nuptiality after the Great Patriotic War is noted. The development of the Russian family is associated with housing conditions and the formation of the housing market. Among nuclear families, the parent-child family stands out, which is interpreted as the main family from the standpoint of reproductive and social reproduction and the immediacy of contacts between two generations. The features of the main family are emphasized: the presence of a heterogeneous married couple and one or two dependent children.
\end{abstract}

\begin{abstract}
Attention is drawn to the increasing diversity of main families and their modifications in the context of the characteristics of the family, the nature of marital and intrafamilial relations. The bottlenecks of domestic statistics are noted, which complicate the analysis of marriage and family relations. A conclusion is made about the ambivalence of modern Russian society and the nonlinearity of the process of family modernization, including recurrent tendencies.
\end{abstract}

Key words: main family, family structure, married couple, legislation, depended children, type of family, female preponderance, abortion, dwelling, tendency.

Irina Eliseeva (irinaeliseeva@mail.ru), St. Petersburg State University of Economics, SOCIOlOGiCAL INSTITUTE OF THE RUSSIAN ACADEMY OF SCIENCES - A BRANCH OF THE FEDERAL CENTER OF THEORETICAL AND APPLIED SOCIOLOGY OF THE RUSSIAN ACADEMY OF SCIENCES, RUSSIA.

DATE RECEIVED : SEPTEMBER 2020

\section{REFERENCES}

Antsiferov A.N. Bilimovich A.D., Batshev M. O., Ivantsov D.N. (1930). Russian Agriculture during the War. New Haven: Yale University Press.

Andreyev E.M., Darskiy L.E., Khar'kova T.L. (1993). Naseleniye Sovetskogo Soyuza, 19221991 [Population of the Soviet Union, 1922-1991]. Moscow: Nauka. (In Russ.).

Andreyev E.M., Darskiy L.E., Khar'kova T.L. (1998). Demograficheskaya istoriya Rossii.. 1927-1959 [Demographic history of Russia 1927-1959]. Moscow: Informatika. (In Russ.)

Antonov A.I. (2016). Krizis familisticheskoy tsivilizatsii v XXI veke. [The crisis of familistic civilization in the 21st century]. Ekonomicheskiye strategii [Economic Strategies], 1, 40-43. (In Russ.).

Antonov A.I., Borisov V.A. (1990). Krizis sem'i i puti ego preodoleniya. Nauchnyy doklad [Family crisis and ways to overcome it. Scientific report]. Moscow: Institut sotsiologii AN SSSR. (In Russ.). 
Antonov A.I., Borisov V.A. (2011). Lektsii po demografii [Demography lectures]. Moscow: Akademicheskiy proyekt; Al'ma Mater. (In Russ.).

Belova V.A. (1975). Chislo detey v sem'ye [Number of children in the family]. Moscow: Statistika. (In Russ.).

Belova V.A., Darskiy L.E. (1972). Statistika mneniy v izuchenii rozhdayemosti [Opinion statistics in the study of fertility]. Moscow: Statistika. (In Russ.).

Berger L.M., McLanahan S. (2015). Income, Relationship Quality and Parenting Associations with Child Development in Two-Parent Families. Journal of Married and Family, 77(4), 996-1015. DOI: https://doi.org/10.1111/jomf.12197

Bim-Bad B.M., Gavrov S.I. (2010). Modernizatsiya instituta sem 'i. [Modernization of the family institution]. Moscow: Intellektual'naya kniga, Novyy khronograf. (In Russ.).

Borisov V.A. (1976). Perspektivy rozhdayemosti. [Fertility prospects]. Moscow: Statistika. (In Russ.).

Boym S. (2002). Obshchiye mesta. Mify povsednevnoy zhizni. [Common places. Myths of everyday life]. Moscow: Novoye literaturnoye obozreniye. (In Russ.).

Burmykina O.N. (2015). Mezhpokolennyye vzaimodeystviya v sem’ye: podderzhka i sotsial'nyye seti. [Intergenerational Family Interactions: Support and Social Media] In I.I. Eliseyeva, An'tsi Syuy (Red.), Sem'ya v Rossii i Kitaye. Protsess modernizatsii [Family in Russia and China. Modernization process] (pp. 199-232). St-Petersburg: Nestor-Istoriya. (In Russ.)

Burmykina O.N. (2018). Dinamika predstavleniy peterburgskikh studentov o sem'ye i mezhpokolennykh otnosheniyakh (2007-2017 gg.) [Dynamics of ideas of St. Petersburg students about the family and intergenerational relationships (2007-2017).]. Peterburgskaya sotsiologiya segodnya, 9, 27-46. (In Russ.).

Burton N. (2020). What Future for Family? Families are becoming much more diverse. URL: https://www.psychologytoday.com/ca/blog/hide-and-seek/201708/what-future-the-family

Chikalova E.A. (2016). Ottsovstvo v fokuse zapadnykh sotsiologicheskikh i psikhologicheskikh issledovaniy: problemy i perspektivy [Fatherhood in the Focus of Western Sociological and Psychological Research: Problems and Prospects]. Peterburgskaya sotsiologiya segodnya, 7, 201-215. (In Russ.).

Chizhova Zh.G., Shestakova V.N., Punina M.A. (2010). Osobennosti sem'i i braka na sovremennom etape razvitiya obshchestva [Features of family and marriage at the present stage of development of society]. Vestnik Smolenskoy meditsinskoy akademii, 4, 57-66. (In Russ.).

De Tangi A. (2012). Velikaya migratsiya: Rossiya i rossiyane posle padeniya zheleznogo zanavesa [The Great Migration: Russia and Russians after the Fall of the Iron Curtain]. Moscow: ROSSPEN.

Dekrety sovetskoy vlasti [Soviet decrees] (1957). Vol.1. Moscow: Politizdat. (In Russ.).

Eliseeva I.I. (2018a). Izmeneniya rozhdayemosti i sem'i. [Fertility and family changes]. In I.I. Eliseeva (Ed.), Novaya znachimost' sem'i dlya Rossii i Kitaya [The new significance of the family for Russia and China] (pp. 65-87). St.-Petersburg: Renome. (In Russ.)

Eliseeva I.I. (2018b). Rozhdeniya i nerozhdeniya. [Births and non-births]. Peterburgskaya sotsiologiya segodnya, 10, 204-221. (In Russ.). 
Eliseeva I.I., Vasil'yeva E.K. (2014). Osnovnyye napravleniya issledovaniya domashnikh khozyaystv po materialam vserossiyskikh perepisey naseleniya [The main directions of research of households based on the materials of all-Russian population censuses]. Voprosy statistiki, 5, 32-40. (In Russ.).

Erofeyeva L.V. (2017). Politika v sfere reproduktivnogo zdorov'ya v Rossii i mezhdunarodnyy opyt [Reproductive health policy in Russia and international experience]. Demographic Journal, 2, 22-29. (In Russ.).

Golod S.I. (1998). Sem'ya i brak: istoriko-sotsiologicheskiy analiz. [Family and marriage: a historical and sociological analysis]. St.-Petersburg: TOO TK «Petropolis». (In Russ.).

Golod S.I. (2005). Chto bylo porokami, stalo normami [What was vices became norms]. Moscow: Ladomir. (In Russ.).

Guggenbyul'-Kreyg A. (2007). Brak umer - da zdravstvuyet brak! [The marriage is dead - long live the marriage!]. Moscow: Kogito-Tsentr. (In Russ.).

Gurko T.A. (2010). Teoreticheskiye podkhody k izucheniyu sem 'i. [Theoretical approaches to the study of the family]. Moscow: Institut sotsiologii RAN. (In Russ.).

Gurko T.A. (2017). Novyye semeynyye formy: tendentsii rasprostraneniya i ponyatiya. [New family forms: distribution trends and concepts]. Sociological Studies, 11, 99-110. (In Russ.).

Gurko T.A. (2020). Ponyatiye ambivalentnosti v izuchenii semeynykh otnosheniy. [The concept of ambivalence in the study of family relationships]. Sociological Studies, 2, 63-73. (In Russ.).

Interv'yu tov. I.V. Stalina s korrespondentom gazety «Pravda» otnositel'no rechi g. Cherchillya [Interview Comrade JV Stalin with the correspondent of the newspaper "Pravda" regarding the speech of Mr. Churchill] (1946). Bol'shevik, 5, Mart, 1-5. (In Russ.).

Kavelin K.D. (2019). Mysli i zametki o russkoy istorii [Thoughts and notes on Russian history]. Moscow: Yurayt. (In Russ.).

Kletsin A.A. (2000). Ocherk istorii sotsiologii sem 'i [Essay on the history of family sociology]. St.-Petersburg: Petropolis. (In Russ.).

Kletsin A.A. (2003). Raspredeleniye domashnikh obyazannostey mezhdu suprugami: fakty, problemy, interpretatsiya. [Distribution of household responsibilities between spouses: facts, problems, interpretation]. Zhurnal sotsiologii i sotsial'noy antropologii, VI(2). URL: http://ecsocman.hse.ru/data/557/818/1219/Kletsin.pdf (In Russ.).

Laptev I.(1946). Sila i zhiznennost' kolkhoznogo stroya [The strength and vitality of the collective farm system]. Bol'shevik, 4, 25-37. (In Russ.).

Mazur L.N. (2015). Istoriya rossiyskoy sem 'i: problemy tipologii. [History of the Russian family: problems of typology]. Vyp. 15. Ekaterinburg: Izdatel'stvo Ural'skogo universiteta. (In Russ.).

Mironov B. N. (2017). Rossiyskaya revolyutsiya 1917 goda skvoz' prizmu demograficheskoy modernizatsii [The Russian revolution of 1917 through the prism of demographic modernization]. Demographic Review, 4 (4), 6-58. (In Russ.).

Mironov B.N. (2015). Rossiyskaya imperiya: ot traditsii k modernosti. V 3 tomakh. T.2 [Russian Empire: From Tradition to Modernity. In 3 volumes. T.2.]. St.-Petersburg: Izdatel'stvo «Dmitriy Bulanin». (In Russ.). 
Nechayeva N.A. (2019). Gendernaya kartina mira: k opredeleniyu ponyatiya i ego struktury [Gender picture of the world: towards the definition of the concept and its structure]. Peterburgskaya sotsiologiya segodnya, 12,114-133. (In Russ.).

Noks A. (2014). Vmeste s russkoy armiyey. 1914-1917. Dnevnik voyennogo attashe [Together with the Russian army. 1914-1917. Diary of a military attaché]. Moscow: ZAO Tsentrpoligraf. (In Russ.).

OECD (2011). The Future of Families to 2030. URL: https://www.oecd.org/futures/49093502.pdf

Rosset E. (1974). Printsipy i problemy perspektivnoy politiki narodonaseleniya. Per. s pol'sk. [Principles and problems of prospective population policy. Tran. from Polish]. In V.S. Steshenko, V.P. Piskunova (Eds.), Demograficheskaya politika [Demographic policy]. Moscow: Statistika. (In Russ.).

Rosstat (2002). Vserossiyskaya perepis' naseleniya 2002 goda [2002 All-Russian Population Census]. URL: http://www.perepis2002.ru/index.html?id=11 (In Russ.).

Rosstat (2008). Sem'ya v Rossii. 2008 [The Family in Russia. 2008]. URL:http://rosstat.gov.ru/bgd/regl/b08_69/MAIN.htm (In Russ.).

Rosstat (2010). Vserossiyskaya perepis' naseleniya 2010 goda [2010 All-Russian Population Census]. URL: https://rosstat.gov.ru/free_doc/new_site/perepis2010/croc/perepis_itogi1612.htm (In Russ.).

Rosstat (2019). Demograficheskiy ezhegodnik Rossii.2019 [The Demographic Yearbook of Russia. 2019]. URL:http://rosstat.gov.ru/bgd/regl/B19_16/MAIN.htm

Rudyk O.I. Evolyutsiya instituta braka v sovetskom semeynom prave (1917-1996) [The evolution of the institution of marriage in Soviet family law] (avtoref. diss. na soiskaniye uch. step. kand. yuridich. nauk). Nizhegorodskaya akademiya MVD RF. (In Russ.)

Ruzhzhe V.L., Eliseeva I.I., Kadibur T.S. (1983). Struktura i funktsii semeynykh grupp [The structure and functions of family groups]. Moscow: Finansy i statistika. (In Russ.).

Rybakovskiy L.L. (2001). Velikaya Otechestvennaya: lyudskiye poteri Rossii [Great Patriotic War: human losses in Russia]. Sociological Studies, 6, 85-95. (In Russ.).

Sakevich V.I. (2017). Tendentsii i problemy v sfere vnutrirossiyskogo regulirovaniya rozhdayemosti v Rossiyskoy Federatsii [Trends and problems in the field of domestic Russian birth control in the Russian Federation]. Demograficheskiy zhurnal, 2, 14-20. (In Russ.).

Saltykov-Shchedrin M.E. (1988). Pis'ma k teten 'ke. Sobr. soch. v desyati tomakh. Tom sed'moy [Letters to my aunt. Coll. op. in ten volumes. Volume seven.]. Moscow: Izdatel'stvo «Pravda». URL: http://az.lib.ru/s/saltykow_m_e/text_0385.shtml (In Russ.).

Sinel'nikov A.B. (2015). Predely rasshireniya granits sem'i i braka [The limits of expanding the boundaries of family and marriage]. Vestnik Moskovskogo universiteta. Seriya 18. Sotsiologiya i politologiya, 1, 90-108. (In Russ.).

Tsentral'noye statisticheskoye upravleniye (1928a). Vsesoyuznaya perepis' naseleniya 1926 goda. T.5 [All-Union Population Census of 1926. Vol. 5]. Moscow-Leningrad. (In Russ.).

Tsentral'noye statisticheskoye upravleniye (1928b). Zhilishchnyy fond SSSR. Census Division. Issue 6. (In Russ.).

Tsentral'noye statisticheskoye upravleniye (1933). Vsesoyuznaya perepis' naseleniya $1926 \mathrm{~g}$. T.55 [All-Union Population Census of 1926. Vol. 55]. (In Russ.). 
Tsentral'noye statisticheskoye upravleniye (1962). Itogi Vsesoyuznoy perepisi naseleniya 1959 goda. SSSR [Results of the 1959 All-Union Population Census. USSR]. Moscow: Gosstatizdat. (In Russ.).

Tsentral'noye statisticheskoye upravleniye (1963). Itogi Vsesoyuznoy perepisi naseleniya 1959 goda. RSFSR. [Results of the 1959 All-Union Population Census. RSFSR]. Moscow: Gosstatizdat. (In Russ.).

Tsentral'noye statisticheskoye upravleniye (1974). Itogi Vsesoyuznoy perepisi naseleniya 1970 goda. T. VII [Results of the 1970 All-Union Population Census. Vol. VII. Moscow: Statistika. (In Russ.).

Tsetkin K. (1955). Vospominaniya o Lenine [Memories of Lenin]. Moscow: Gospolitizdat. (In Russ.).

Uells G. (1958). Rossiya vo mgle [Russia in the darkness]. Moscow: Gospolitizdat. (In Russ.).

Vasil'yeva E.K. ( 1985). Sem'ya v sotsialisticheskom obshchestve. [Family in a socialist society]. Moscow: Mysl'. (In Russ.).

Vasil'yeva E.K. (1975). Sem'ya i eye funktsii [Family and its functions]. Moscow: Statistika. (In Russ.).

Vishnevsky A.G. (2006). Demograficheskaya modernizatsiya Rossii [Demographic modernization of Russia. 1990-2000]. 1990-2000 Moscow: Novoye izdatel'stvo. (In Russ.).

Vishnevsky A.G. (2008a). Evolyutsiya rossiyskoy sem'i. [Evolution of the Russian family: XX century: from a peasant family to an urban one]. Ekologiya $i$ zhizn', 7 URL: https://elementy.ru/nauchno-populyarnaya_biblioteka/430650/Evolyutsiya_rossiyskoy_semi (In Russ.).

Vishnevsky A.G. (2008b). Evolyutsiya rossiyskoy sem'i: KhKh vek: ot krest'yanskoy sem'i k gorodskoy [Evolution of the Russian family: XX century: from a peasant family to an urban one]. Ekologiya i zhizn', 8 URL: https://elementy.ru/nauchnopopulyarnaya_biblioteka/430651/Evolyutsiya_rossiyskoy_semi_prodolzhenie 1 (In Russ.).

Vishnevsky A.G. (2019). Demograficheskaya istoriya i demograficheskaya teoriya. [Demographic history and demographic theory] uchebnik VSHE. Moscow: Izd. dom Vysshey shkoly ekonomiki. (In Russ.).

Vishnevsky A.G., Zakharov S.V., Ivanova E.I. (2008). Evolyutsiya rossiyskoy sem'i: sovremennaya rossiyskaya sem'ya. Obshchaya kartina [The evolution of the Russian family: the modern Russian family. The big picture]. Ekologiya i zhizn', 9. URL:

https://elementy.ru/nauchnopopulyarnaya_biblioteka/430652/Evolyutsiya_rossiyskoy_semi_okonchanie (In Russ.).

Volkov A.G. (1999). Evolyutsiya rossiyskoy sem'i v XX veke. [Evolution of the Russian family in the XX century]. Mir Rossii, VIII(4), 47-57. (In Russ.).

Volkov A.G. (2014). O nekotorykh prichinakh snizheniya koeffitsiyenta rozhdayemosti. [On some reasons for the decline in the birth rate]. In Volkov A.G., Izbrannyye demograficheskiye trudy (pp. 521-529). Moscow: Izd. dom Vysshey shkoly ekonomiki.

Volkov A.G., Soroko E.L. (1999). Tipologiya semey i domokhozyaystv v Rossii: razvitiye i analiz [Typology of families and households in Russia: development and analysis]. Voprosy statistiki, 5, 40-52. (In Russ.).

Voronina O.A. (2018). Gendernaya kul'tura v Rossii: traditsii i novatsii [Gender Culture in Russia: Traditions and Innovations]. Moscow: IF RAN. (In Russ.). 
Yyensen R. (2002). Obshchestvo mechty [Dream Society]/ per s angl. St.-Petersburg: Stokgol'mskaya shkola ekonomiki. (In Russ.).

Zakharov S.V. (2007). Transformatsiya brachno-partnerskikh otnosheniy v Rossii: «zolotoy vek» traditsionnogo braka blizitsya k zakatu? [Transformation of marriage and partnership relations in Russia: is the "golden age" of traditional marriage approaching its end?] In T.M. Malevaya, O.V. Sinyavskaya (Eds.), Roditeli i deti, muzhchiny $i$ zhenshchiny $v$ sem'ye $i$ obshchestve. Vyp. 1 [Parents and children, men and women in the family and society. Iss. 1] (pp. 75-126). Moscow: NISP. (In Russ.).

Zakharov S.V. (2016). Rozhdayemost' v Rossii v period pronatalizma [Fertility in Russia during the period of pronatalism]. Rossiya 2016. Ezhegodnyy doklad Franko-rossiyskogo analiticheskogo tsentra Observo, Pod ruk. A. Dyub'yena (pp. 320-325). Moscow- Parizh: Observo. Analiticheskiy tsentr pri franko-rossiyskoy torgovo-promyshlennoy palate. (In Russ.).

Zherebin V.M. (Ed.) (2010). Resursnyy potentsial zhiznennogo tsikla sem 'i [Resource potential of the family life cycle]. Moscow: Nauka. (In Russ.).

Zhid A. (1990). Vozvrashcheniye iz SSSR [Return from the USSR]. Moscow: Izdatel'stvo politicheskoy literatury. (In Russ.).

Zhiromskaya V.M. (Ed.) (2001). Naseleniye Rossii v XX v. Istoricheskiye ocherki. T.2. 19401959 [The population of Russia in the twentieth century. Historical sketches. Vol. 2. 19401959.]. Moscow: ROSSPEN. (In Russ.).

Zinov'yev A.A. (2019). Sovetskaya epokha. Ispoved'otshchepentsa [Soviet era. Renegade confession]. Moscow: Rodina. (In Russ.). 